\title{
The impact of information technology on business transformation in the operating telecommunications companies in Jordan
}

Abeer Sufian and Mohammed Otair

ABSTRACT:

Amman Arb University, Department of Computer Science, Jordan

The study aims at measuring the effects of information technology on the transformation of businesses in communication companies in Jordan. The study population consisted of companies' directors as well as their deputies, assistants, advisors, in addition to department managers and their assistants. The total number of the study subjects is 3 designated communication companies in Jordan; these are: Zain, Umniah, and Orange. To achieve the aim of the study, the researcher had prepared a questionnaire which comprises of 45 items covering the three factors of the independent variable (Information Technology): infrastructure, developmental environment, and executive support systems and applications, as well as the three factors of the dependent variable (Transformation of Businesses): operations, organization change, and workers' competence. In order to test the hypotheses, the following three criteria were adequately used: The Medians, the Standard Deviations, as well as the Regression Analysis. The study has reached a number of results; the most notable amongst these results is that there is a positive effect that is statistically significant of information technology on the elements of business transformation in Jordanian communication companies and all of their relating elements.

The last decade of the twentieth century and the turn of twenty-first century witnessed significant progress in technology in general and information technology and communication in particular. Such progress still continues until today, accelerating with wide quick strides more than ever. This age has produced many mechanisms for manufacturing knowledge and more advanced technological means that have made the globe as a small village. Communication technology, which is represented by the internet, has played a huge rule in transferring information and technological revolution from the north to the south passing by the east and the west at the same time. All of that have had an impact on all political, economic, educational, teaching, social, media, and advertisement systems in all communities.

The term technology is derived from Greek. It consists of two parts, techno, which means skills or art, and logy, which means science or study. Thus, the word technology means the science of performance, science of implementation, or the technical methods to achieve a practical purpose, the science of industrial operation.

\section{THE TRANSFORMATION OF BUSINESS:}

It is the change resulting from the discrimination on the bases of the ability to affect change and not on the bases of upon whom the act of change occurs, which provides the ability to commence a special ongoing change process, creating a structural transformation that can face challenges and exploit available opportunities in a widely changing, open, intertwining environment (Al-Mashaikhi, 2019).

\section{THE OBJECTIVE OF THE STUDY:}

The purpose of this study is to identify and measure the effect of the IT in its dimensions (infrastructure, developmental environment, executive support system and applications) on the transformation of business in its dimensions (operation, organizational change, and workers' competence) in communication companies in Jordan, and the difficulties, limitations, and opportunities that are provided for the organization. 


\section{THE IMPORTANCE OF THE STUDY:}

The importance of the study stems from the fact that it deals with a modern and vital topic; therefore, it significantly represents the effects of information as well as communication technology on the transformation of the booming business environment which is specifically noteworthy in many telecommunications companies as a result of the transition of the economy from global to a knowledge-based economy. Competitive advantage and value creation are linked to the challenging ability of today's organizations to convert acquired knowledge into a direct means of production which reflects the growing and accelerating importance of the social and human capital, or what has become known to be called as the factor of knowledge in the organization in the processes of generating ideas and solutions, making strategic decisions, and improving services and goods. This requires a different structure of the hierarchy of authority in the organizations which in result will allow for higher flexibility, hence making it different from the traditional management that the science of management adopted throughout its long history of implementation.

\section{THE HYPOTHESES OF THE STUDY:}

\section{THE INTRODUCTION:}

This study and its questions are basically based on previous conducted studies related to the effect of IT on the Transformation of business in the operating telecommunication companies in Jordan; the study aims to prove the following hypotheses.

\section{THE HYPOTHESES}

The Main hypothesis: There is no significant effect that is proven statistically at the ratio of $(\alpha=0.05)$ for IT in its three main dimensions: (1- the infrastructure, 2- the development environment, 3- the executive support system and applications on the business transformation in its three main dimensions (the operations, the organizational change, the employee' efficiency) in telecommunications companies in Jordan.

Three minor hypotheses branch out from this main hypothesis:

First minor hypothesis: There is no significant effect that is proven statistically at the ratio of $(\alpha=0.05)$ of the IT (the infrastructure, the developmental environment, executive support system and applications) on the operations in the telecommunication companies in Jordan.

The second sub-hypothesis: There is no significant effect that is proven statistically at the ratio of $(\alpha=$ 0.05 ) of the IT (the infrastructure, the developmental environment, executive support system and applications) on the organizational change in the telecommunications companies in Jordan.

There is no significant effect that is proven statistically at the ratio of $(\alpha=0.05)$ of the IT (the infrastructure, the developmental environment, executive support system and applications) on the employees' efficiency in the telecommunications companies in Jordan.

\section{The Study model:}

In light of the researcher's reviews of previous literature and related studies as well as the study problem and its elements, the following figure was prepared, which illustrates the variables, elements and relationships of the topic. 


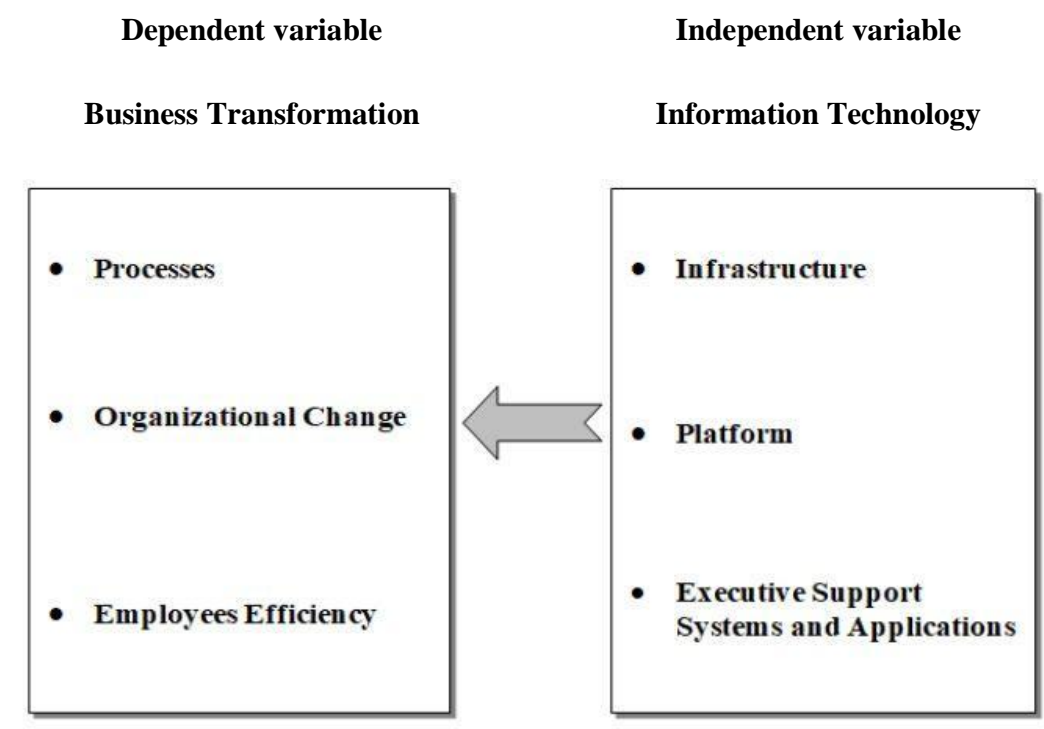

Figure 1.the study model

The model is prepared by the researcher based on the following main references:

- $\quad$ The (Independent) variable elements based on (2011 Gartner) and (2013 EMC Corporation).

- The (Dependent) variable elements based on (2013 Don Saracen) and (2009, McGuire et al).

The model which is prepared by the researcher is based on the following two main references:

1. The (Independent) variable elements.

2. The (Dependent) variable elements.

\section{THE PREVIOUS STUDIES:}

\section{-Al Shobaki. 2018- The Reality of Computerized Management Information.}

The study was conducted with regard to the Palestinian current reality which was conducted by the researcher regarding the Modern information technology and its impacts on the administrative decisions in the business organizations.

This study aimed to discuss the advantages that the Palestinian business organizations in the Gaza Strip can achieve as a result of their efficient use of the modern information technology; the study population consisted of limited public shareholding companies as well as the Palestinian solidarity companies in the Gaza Strip; the descriptive and analytical approach was used; the questionnaire was distributed to (126) of the companies mentioned above; the number of questionnaires which were received was (71). The study concluded that many Palestinian companies actually do not use basic information technology practices; it also arrived at the conclusion that managers' lack of knowledge and the knowledge of the significance of the Internet is because of their incompetency and lack of capabilities in the English language. The study recognized the importance of making a shift in the traditional administrative systems that are used in the Palestinian companies as well as keeping pace with modern technological development. 


\section{-AK Kariuki (2015) The Impact of information technology on organizational performance.}

The study aimed to find out the levels of the information and the communication technology tools which are mainly used in the industrial companies in Jordan; The study population consisted of all the Jordanian industrial public shareholding companies which are listed in the Amman Financial Market mainly for the year (2004), the number of these chosen companies was 85. The sample was collected by relying on the officially declared capital of these companies; (153) questionnaires were distributed to the top management managers, and a percentage of $(75 \%)$ of these questionnaires were recovered; the descriptive and analytical method was used to address it.

The study concluded that the majority of the Jordanian industrial companies have a designated computer department which managers do use it in the carrying out their work, even on partial basis, also, (79\%) of these companies do not have an internal network for their devices; the study recommended the activation of the use of modern information and communication technology tools such as: having an internal link of devices between different departments and making use of the capacities and capabilities of these technologies in the carrying out of business.

\section{E- Erdurmazlı- Jun 18, 2020, the Effects of Information Technologies on Organizational Culture.}

The study argues that information technologies can have direct impact on the performance of telecommunication companies and is considered as an important tool of how groupware use affects communication and collaboration among operating telecommunication companies.

This study aimed to find out the effects of using information technology on the success of projects in the ICT sector in Jordan; the study population in this study consisted of the 200 ICT companies in Jordan until the year 2011. Both the arithmetic means and the standard deviation were used to extract the results of the hypotheses. Several conclusions have been achieved; the most important of these conclusions was the presence of an effect of the elements and characteristics of information technology regarding the success of projects in the ICT sector. The study recommended increasing awareness of the concept of information technology because of its great role in improving the level of performance; moreover, the study recommended highlighting the importance of providing devices, hardware, software and databases in all the project activities.

\section{J-Cepeda $\cdot 2019$, The Information technology capabilities and organizational agility.}

This study aimed to understand the link between information technology capabilities and organizational agility. Researchers have classified information technology capabilities into three dimensions which include: IT infrastructure capabilities, IT business expansion capabilities, and IT proactive stance. The sample consisted of (128) individuals working in the field of information technology, and the descriptive and analytical method was used. The study has reached many results, the most prominent of these results is the perceptible existence of a connection between the competences of the information technology infrastructure and the expansion of the business capabilities. The study recommended adopting an advanced infrastructure for information technology and advanced applications and systems. 


\section{BA NOURI • 2020, the Effect of cooperative management on organizational agility.}

The study aimed at transforming business through the transformation in information technology; the study focused on the Chief Executive Officer's role (CIO) in making information technology a creator of change within the organizations as well as empowering the employees to achieve the highest level of performance.

It also addresses the change in the CIO's priorities. IT leaders have the imperative to transform the relationship between IT and the rest of the business. The study concluded that there are new economies in information technology.

The competitive advantage will depend on the organizations' ability to assist IT investments in new business ways where the ability that is emerging through the new economies of information technology is to find new sources of revenue and accordingly not only sources of competitive advantage but also new roles for the CIO.

\section{S-Panda $\cdot 2018$ - Information technology capability and knowledge management.}

This study aimed to define the five main principles in defining "the cloud" as defined by the National Institute of Standards and Technology (NIST); these five main principles are: rapid flexibility, demanddriven and self-service, resource pooling, wide network access, and service of measurement.

The study concluded that "cloud computing" has been classified into two categories; the study also concluded that with the help of a group of technologies (Virtualization, Cloud Computing, and ITaaS), the competitive advantage, the innovation and the efficiency can be achieved. In addition; there are four main focal points in the transformation from IT to ITaaS. In the end, the study found that there are a number of success factors, the most important of these factors are: competitiveness, innovation, customer experience, profitable business, and value-based decisions.

\section{THE METHODS AND PROCEDURES:}

\section{THE STUDY POPULATION:}

As discussed earlier, the main study population of the study consisted of all operating telecommunications companies in Jordan which at the end of the year 2014 were three, companies that included: Zain, Orange, and Umniah and are still as until the present date.

\section{THE INSPECTION AND ANALYSIS UNIT:}

The Inspection and Analysis Unit consisted of the directors, deputies, assistants, consultants, heads of departments, and assistants to heads of departments; these represent the higher departments in the telecommunication companies and are responsible for the information and communication technology.

\section{THE SOURCES OF THE STUDY DATA:}

The sources of study data are primary sources that were collected through direct reference to the study sample as well as secondary sources which were obtained from research papers, reports, articles, and books. 


\section{THE STATISTICAL ANALYSIS OF THE STUDY DATA AND THE HYPOTHESIS TESTS:}

\section{THE DEMOGRAPHIC CHARACTERISTICS ANALYSIS OF THE STUDY SAMPLE.}

The percentage of the study sample individuals under the age of (40) in general was about (82.7\%) and those over the age of (40) years formed (17.4\%) of the total study sample. The study sample of those who hold university degrees (Bachelor's degree) constituted (76\%) and those holding an intermediate diploma certificate or less constituted (20\%), while those with higher degrees (such as: higher diploma, master's, or doctorate) was (4\%) of the total sample.

Based on the previous characterization of the sample study, it can be concluded that the sample is characterized according to diversity for the reason that it includes a different range of scientific specializations with the holders of bachelor's degree at the top.

The study sample included several job levels, the highest percentage of department heads was (20\%) followed by the heads of people and workers in the administrative fields with a percentage of (34.6\%), afterwards the supervisors and workers in engineering fields; these formed a percentage of (21.4\%). With regard to managers and technical workers, their percentage was $(10.4 \%)$ of the total study sample. Depending on the given statistics, it has become clear to us that the study sample has an appropriate representation of all job levels.

The following table shows that:

\begin{tabular}{|c|c|c|c|c|c|c|c|c|}
\hline $\begin{array}{c}\text { Company } \\
\text { name }\end{array}$ & $\begin{array}{c}\text { General } \\
\text { managers of the } \\
\text { companies }\end{array}$ & $\begin{array}{c}\text { Deputy } \\
\text { general } \\
\text { managers }\end{array}$ & $\begin{array}{c}\text { Assistant } \\
\text { general } \\
\text { managers }\end{array}$ & \begin{tabular}{|c|} 
Consultant \\
assistants of \\
the General \\
managers \\
\end{tabular} & $\begin{array}{c}\text { Heads of } \\
\text { departments }\end{array}$ & $\begin{array}{l}\text { Heads of IT } \\
\text { departments }\end{array}$ & $\begin{array}{c}\text { Assistants of } \\
\text { the Heads of } \\
\text { IT } \\
\text { departments }\end{array}$ & $\begin{array}{l}\text { The } \\
\text { Total }\end{array}$ \\
\hline Zain & 3 & 3 & 3 & 12 & 3 & 3 & 3 & 30 \\
\hline Umniah & 3 & 3 & 3 & 10 & 3 & 3 & 3 & 28 \\
\hline Orange & 3 & 3 & 3 & 8 & 3 & 3 & 3 & 26 \\
\hline Total & 9 & 9 & 9 & 30 & 9 & 9 & 9 & 84 \\
\hline
\end{tabular}

The above results showed that $(60 \%)$ of the sample members and who constituted the majority of the study sample had previous experiences which exceeded (5) years; however, the percentage of those who had experiences that are less than (5) years was about (40\%), based on the attained results, it is evident that the employees have had good and sufficient experience; this was reflected in their answers to the questionnaire.

\section{THE RESULTS OF ANALYZING THE MEANS FOR THE ELEMENTS AND VARIABLES OF THE STUDY:}

\section{THE ANALYSIS OF THE MEANS AND VARIABLES OF THE INFORMATION TECHNOLOGY:}

The implementation of the information technology includes the implementation of three main variables as they all together measure the extent of the implementation of information technology as a whole; these 
variables include: the infrastructure, the development environment, systems and implementation of executive support.

\section{THE FIRST VARIABLE:}

\section{THE INFRASTRUCTURE}

The lowest arithmetic mean was " 4.320 " out of "5", or equivalent to " $86.4 \%$ ", while the second article was(the company has the technical support for basic information technology resources, devices, checks, software, and storage media); this indicates that that there is a need for some improvement and the increase of interest in telecom companies in order to strengthen the technical support for information technology.

As for the highest arithmetic mean, it was " 4.373 " out of " 5 ", or equivalent to " $87.5 \%$ ". As for the first two articles which were: (the company has had an integrated information technology infrastructure in terms of devices, checks, system software, and the necessary and storage capacities); as for the fifth article, (the company can regulate, control and protect the infrastructure resources (such as: devices, networks, software and storage capacities).

This indicates that there is great concurrence on the availability of the necessary infrastructure in Jordan telecommunications companies. As for the general mean of the infrastructure variable, it has reached " 4,355 " out of 5, which equals to $87.1 \%$. This indicated that the sample population highly believe that the telecommunications companies in Jordan have suitable IT infrastructures.

\begin{tabular}{|c|l|c|c|c|c|}
\hline Number & \multicolumn{1}{|c|}{ Article } & $\begin{array}{c}\text { Arithmetic } \\
\text { mean }\end{array}$ & $\begin{array}{c}\text { Arithmetic } \\
\text { mean \% }\end{array}$ & $\begin{array}{c}\text { Standard } \\
\text { deviation }\end{array}$ & $\begin{array}{c}\text { Importance } \\
\text { level }\end{array}$ \\
\hline $\mathbf{1}$ & $\begin{array}{l}\text { The company has an integrated IT infrastructure in terms of } \\
\text { hardware, networks, system software and the necessary } \\
\text { storage capacities. }\end{array}$ & 4.373 & $87.5 \%$ & 0.514 & High \\
\hline $\mathbf{2}$ & $\begin{array}{l}\text { The company has technical support for basic information } \\
\text { technology resources (hardware, networks, software and } \\
\text { means of storage). }\end{array}$ & 4.320 & $86.4 \%$ & 0.524 & High \\
\hline $\mathbf{3}$ & $\begin{array}{l}\text { The company has an infrastructure which is flexible in order } \\
\text { to be able to install various applications and software in } \\
\text { terms of (hardware, networks, software and storage means). }\end{array}$ & 4.347 & $86.9 \%$ & 0.533 & High \\
\hline $\mathbf{4}$ & $\begin{array}{l}\text { The company is constantly reviewing the infrastructure } \\
\text { resources with the intention of updating and developing the } \\
\text { infrastructure components such as: hardware, networks, } \\
\text { software, and storage means. }\end{array}$ & 4.360 & $87.2 \%$ & 0.561 & High \\
\hline $\mathbf{5}$ & $\begin{array}{l}\text { The company has the ability to regulate and protect } \\
\text { resources such as: infrastructure, hardware, networks, } \\
\text { software, and storage media). }\end{array}$ & 4.373 & $87.5 \%$ & 0.514 & High \\
\hline & The General average of the infrastructure variable & $\mathbf{4 . 3 5 5}$ & $\mathbf{8 7 . 1} \%$ & $\mathbf{0 . 5 2 9}$ & High \\
\hline
\end{tabular}

\section{THE SECOND VARIABLE:}

\section{THE DEVELOPMENTAL ENVIRONMENT}

The lowest arithmetic mean was of the seventh article (the company has the adequate technical support for the components of the development environment); the arithmetic mean of seventh article was " 4.293 " out of 
"5" or " $85.9 \%$ ", hence reflecting the need for the telecommunications companies in Jordan to make more improvement with regard to this aspect.

The highest average mean was for the sixth article (the company has an integrated development environment in terms of tools and software ready for the system development process, programming languages, support services and applications that are needed in its various stages); the average was "4.413" out of "5" or " $88.3 \%$ ".

This indicates a great conviction among respondents that telecommunications companies in Jordan are keen to provide an integrated development environment in terms of ready-made tools and software.

The general arithmetic mean of the articles of the developmental environment variable as a whole was " 4,352 " or " $87 \% "$ which means that the respondents of the study sample highly believe that telecommunications companies in Jordan provide a suitable development environment of their businesses.

\begin{tabular}{|c|c|c|c|c|c|}
\hline Number & Article & \begin{tabular}{|c|}
$\begin{array}{c}\text { Arithmetic } \\
\text { mean }\end{array}$ \\
\end{tabular} & $\begin{array}{c}\text { Arithmetic } \\
\text { mean \% }\end{array}$ & $\begin{array}{l}\text { Standard } \\
\text { deviation }\end{array}$ & $\begin{array}{c}\text { Importance } \\
\text { level }\end{array}$ \\
\hline 6 & $\begin{array}{l}\text { The company has an integrated development environment in terms } \\
\text { of tools and software ready for the system development process, } \\
\text { programming languages, support services and applications that it } \\
\text { needs in its different stages. }\end{array}$ & 4.413 & $88.3 \%$ & 0.522 & High \\
\hline 7 & $\begin{array}{l}\text { The company has the technical support for the development } \\
\text { environment components. }\end{array}$ & 4.293 & $85.9 \%$ & 0.540 & High \\
\hline 8 & $\begin{array}{l}\text { The company has a diverse development environment available for } \\
\text { developing systems and applications. }\end{array}$ & 4.347 & $86.9 \%$ & 0.533 & High \\
\hline 9 & $\begin{array}{l}\text { The company reviews the development environment with the intent } \\
\text { to integrate and update it continuously to support building, } \\
\text { developing and maintaining the applications that the company } \\
\text { needs. }\end{array}$ & 4.360 & $87.2 \%$ & 0.607 & High \\
\hline 10 & $\begin{array}{l}\text { The company provides the needed technical support and training } \\
\text { which are necessary to use in the development environment, its } \\
\text { management and control of its resources. }\end{array}$ & 4.347 & $86.9 \%$ & 0.557 & High \\
\hline & The General average of the development environment variable & 4.352 & $87.0 \%$ & 0.552 & High \\
\hline
\end{tabular}

\section{THE THIRD VARIABLE:}

\section{THE EXECUTIVE SUPPORT SYSTEMS AND APPLICATIONS:}

The lowest arithmetic mean which is " 4,240 " out of " 5 " or " $84.8 \%$ "; this related to the thirteenth article ( the ease of access to the applications through more than one means by linking to the Web and through simple user interfaces); this reflects the great potential for telecommunications companies in Jordan to improve and facilitate access to applications.

As for the highest arithmetic mean which was "4.307" or $86.1 \%$ "; this related to the fifteenth article (the technical support and the practical training that are available for workers in the use of software applications and systems); this indicates the interest of the telecommunications companies in Jordan to provide technical support and training for workers on the use of the applications and software systems.

The general arithmetic mean of the articles was related to the variable of executive support systems and applications which was " 4,277 " out of " 5 " or " $85.5 \%$ "; this means that the study sample individuals believe 
to a high degree of the ability of the telecommunications companies in Jordan to provide appropriate executive support systems and applications within the working environment of these companies.

\begin{tabular}{|c|c|c|c|c|c|}
\hline Number & Article & $\begin{array}{l}\text { Arithmetic } \\
\text { mean }\end{array}$ & $\begin{array}{l}\text { Arithmetic } \\
\text { mean \% }\end{array}$ & $\begin{array}{l}\text { Standard } \\
\text { deviation }\end{array}$ & $\begin{array}{c}\text { Importance } \\
\text { level }\end{array}$ \\
\hline 11 & $\begin{array}{l}\text { The company has applications and software systems that } \\
\text { cover the scope of the company's work within its various } \\
\text { administrative levels. }\end{array}$ & 4.253 & $85.1 \%$ & 0.548 & High \\
\hline 12 & $\begin{array}{l}\text { The company has software applications and systems that } \\
\text { cover the specific work of the company, such as decision } \\
\text { support systems (DSS), enterprise resource management } \\
\text { systems (ERP), and other service applications such as } \\
\text { (CRM) and others. }\end{array}$ & 4.293 & $85.9 \%$ & 0.564 & High \\
\hline 13 & $\begin{array}{l}\text { The easy access to the applications through more than one } \\
\text { medium through the network connection (Web) and } \\
\text { through Simpler user Interfaces. }\end{array}$ & 4.240 & $84.8 \%$ & 0.516 & High \\
\hline 14 & $\begin{array}{l}\text { The applications ensure the confidentiality, the protection, } \\
\text { the management and the control of the data and } \\
\text { information. }\end{array}$ & 4.293 & $85.9 \%$ & 0.540 & High \\
\hline 15 & $\begin{array}{l}\text { The support, the technical support, and practical training } \\
\text { are provided for personnel using the software applications } \\
\text { and systems. }\end{array}$ & 4.307 & $86.1 \%$ & 0.519 & High \\
\hline 16 & $\begin{array}{l}\text { The company maintains and develops applications and } \\
\text { systems to meet changing requirements. }\end{array}$ & 4.293 & $85.9 \%$ & 0.540 & High \\
\hline 17 & $\begin{array}{l}\text { The company continually develops high-end applications } \\
\text { that support decision-making and problem-solving } \\
\text { processes. }\end{array}$ & 4.253 & $85.1 \%$ & 0.572 & High \\
\hline \multicolumn{2}{|c|}{$\begin{array}{l}\text { The general average of the variable of systems and applications of } \\
\text { the executive support. }\end{array}$} & 4.277 & $85.5 \%$ & 0.537 & High \\
\hline
\end{tabular}

\section{THE MEANS ANALYSIS OF THE BUSINESS TRANSFORMATION VARIABLES:}

Business transformation includes three main variables which are: operations, organizational change, and workers' competence.

\section{THE FIRST VARIABLE:}

\section{THE OPERATIONS:}

The lowest arithmetic mean was " 4.240 " out of " 5 "; this is equivalent to " $84.8 \%$ "; this related to the eighteenth article (a review of the operations from the perspective of the concept of business transformation); this is important for the telecommunications companies in Jordan so as to be able to make greater efforts in reviewing their operations from a business transformation perspective.

As for the highest arithmetic mean which " 4.373 " out of " 5 "; this is equivalent to "87.5\%"; this related to the twenty-second article (the operations are reviewed to ensure their completion and the achievement of the required results).

As for the general arithmetic mean of the operations variable as a whole; it amounted to "4.336" out of " 5 "; this is equivalent to "86.7\%" which indicates that the respondents believe to a high degree that 
telecommunications companies in Jordan apply appropriate and supportive operations for business transformation within the working environment of these companies.

\begin{tabular}{|c|c|c|c|c|c|}
\hline Number & Article & $\begin{array}{c}\text { Arithmetic } \\
\text { Mean }\end{array}$ & \begin{tabular}{r|} 
Arithmetic \\
Mean\% \\
\end{tabular} & $\begin{array}{l}\text { Standard } \\
\text { Deviation } \\
\end{array}$ & $\begin{array}{c}\text { Importance } \\
\text { Level }\end{array}$ \\
\hline 18 & $\begin{array}{l}\text { The processes are reviewed from the business transformation concept } \\
\text { perspective. }\end{array}$ & 4.240 & $84.8 \%$ & 0.654 & high \\
\hline 19 & $\begin{array}{l}\text { The operations are not viewed as separate, one-time tasks, but rather on } \\
\text { the basis that they are continuous operations and programs. that aim to } \\
\text { monitor the changes that are taking place and are constantly being } \\
\text { reviewed and improved. }\end{array}$ & 4.280 & $85.6 \%$ & 0.605 & High \\
\hline 20 & $\begin{array}{l}\text { The goal and access to active transformation and that is why the } \\
\text { company is keen to make the operations formal. }\end{array}$ & 4.307 & $86.1 \%$ & 0.592 & High \\
\hline 21 & $\begin{array}{l}\text { The company is keen to build a formal model that reflects change and } \\
\text { includes ways to ensure that change is applied and witnessed in the daily } \\
\text { workflow. }\end{array}$ & 4.333 & $86.7 \%$ & 0.577 & High \\
\hline 22 & The Processes are always reviewed to ensure completeness and results. & 4.373 & $87.5 \%$ & 0.540 & High \\
\hline 23 & $\begin{array}{l}\text { The technology which is used has contributed to the increase of } \\
\text { coordination between the different processes. }\end{array}$ & 4.320 & $86.4 \%$ & 0.524 & High \\
\hline 24 & Technology has resulted in making the operations more efficient. & 4.333 & $86.7 \%$ & 0.553 & High \\
\hline 25 & $\begin{array}{l}\text { Technology has supported the innovation and the product development } \\
\text { (goods and services). }\end{array}$ & 4.333 & $86.7 \%$ & 0.528 & High \\
\hline 26 & $\begin{array}{l}\text { The Operations have contributed to improving the value creation chain } \\
\text { through creation, production, distribution and support. }\end{array}$ & 4.320 & $86.4 \%$ & 0.524 & High \\
\hline \multicolumn{2}{|c|}{ The General Average of the Process Variable } & 4.336 & $86.7 \%$ & 0.534 & high \\
\hline
\end{tabular}

\section{THE SECOND VARIABLE:}

\section{THE ORGANIZATIONAL CHANGE:}

The lowest arithmetic mean was " 4.240 " out of " 5 "; this is equivalent to $84.8 \%$; it relates to the thirty-fourth article (it guarantees the performance under the business model to improve the level and the degree of cooperation, coordination and participation between the employees through an organizational structure that ensures flexibility),hence reflecting the need to encourage the Telecommunications companies in Jordan exert greater efforts to improve the level and degree of cooperation, coordination and participation among their working employees.

The highest arithmetic mean which was " 4.400 " out of " 5 "; this is equivalent to " $88 \%$ "; it relates to the twenty-seventh article (technology has contributed to the review of the organizational structures of the company to correspond with the nature of the transformation in business, and in general, the general arithmetic mean of the articles of the change variable Organizational 4.285, which is equivalent to $85.7 \%$, which means that the respondents of the study believe to a high degree that the organizational change in telecommunications companies in Jordan greatly support the business transformation.

\begin{tabular}{|c|c|c|c|c|c|}
\hline Number & Article & $\begin{array}{c}\text { Arithmetic } \\
\text { Mean }\end{array}$ & $\begin{array}{r}\text { Arithmetic } \\
\text { Mean\% }\end{array}$ & $\begin{array}{l}\text { Standard } \\
\text { Deviation }\end{array}$ & $\begin{array}{c}\text { Importance } \\
\text { Level }\end{array}$ \\
\hline 27 & $\begin{array}{l}\text { Technology has contributed to the review of the company's } \\
\text { organizational structure that corresponds to the nature of the } \\
\text { transformation in the business. }\end{array}$ & 4.400 & $88.0 \%$ & 0.569 & high \\
\hline
\end{tabular}


International Journal of Managing Information Technology (IJMIT) Vol.13, No.1, February 2021

\begin{tabular}{|c|c|c|c|c|c|}
\hline 28 & $\begin{array}{l}\text { Technology has contributed in shaping working interrelationships } \\
\text { between the units and individuals within the company. }\end{array}$ & 4.293 & $85.9 \%$ & 0.588 & High \\
\hline 29 & $\begin{array}{l}\text { Technology has contributed to the readiness of performance and the } \\
\text { method by which tasks and duties are distributed. }\end{array}$ & 4.267 & $85.3 \%$ & 0.622 & High \\
\hline 30 & $\begin{array}{l}\text { The company constantly reviews the organization's culture so as to } \\
\text { align it with the business transformation. }\end{array}$ & 4.307 & $86.1 \%$ & 0.615 & High \\
\hline 31 & $\begin{array}{l}\text { Technology has contributed to a review and change of the hierarchy } \\
\text { of authority and authority in the organization. }\end{array}$ & 4.307 & $86.1 \%$ & 0.592 & High \\
\hline 32 & $\begin{array}{l}\text { Technology has contributed to a reconsideration of the lines of chain } \\
\text { of hierarchy and authority among superiors and subordinates. }\end{array}$ & 4.360 & $87.2 \%$ & 0.607 & High \\
\hline 33 & $\begin{array}{l}\text { The organizational structure has to have the ability to change to } \\
\text { transform in order to support a transforming business model because } \\
\text { of the influence of modern technology as well as change in the } \\
\text { business environment, also the openness of environments due to } \\
\text { globalization. }\end{array}$ & 4.267 & $85.3 \%$ & 0.553 & High \\
\hline 34 & $\begin{array}{l}\text { Ensures performance under the business model on improving the } \\
\text { level of cooperation, coordination and participation among } \\
\text { employees through an organizational structure that ensures } \\
\text { flexibility. }\end{array}$ & 4.240 & $84.8 \%$ & 0.541 & High \\
\hline 35 & $\begin{array}{l}\text { The model supports the concept of sharing knowledge among the } \\
\text { company's working employees }\end{array}$ & 4.253 & $85.1 \%$ & 0.496 & High \\
\hline \multicolumn{2}{|c|}{ The General Average of the Organizational Change Variable } & 4.285 & $85.7 \%$ & 0.558 & High \\
\hline
\end{tabular}

\section{THE THIRD VARIABLE:}

\section{THE WORKERS' COMPETENCE:}

The lowest arithmetic mean was " 3.920 " which is equivalent to "78.4\%"; it related to the forty-third article (the company has an appropriate recruitment, a contracting system, and policies that satisfy employees); this reflects the need for the telecommunications companies to constantly review their recruitment and contracting systems and policies.

The highest arithmetic mean amounted to " 4.253 " which is equivalent to " $85.1 \%$ "; it was the share of the thirty-eighth article (the company has a clear and publicized policy in the field of human resources); this means that the respondents strongly agree that telecommunications companies have clear policies.

On the whole, the general arithmetic mean for the articles relating to the employee Competence variable was "4.019" out of " 5 " which is equivalent to " $80.4 \%$ "; this means that the study sample individuals believe with a high degree that the Competence of workers in the telecommunications companies in Jordan is one of the most important elements that contribute to achieving business transformation.

\begin{tabular}{|c|c|c|c|c|c|}
\hline Number & Article & \begin{tabular}{|c|}
$\begin{array}{c}\text { Arithmetic } \\
\text { Mean }\end{array}$ \\
\end{tabular} & $\begin{array}{c}\text { Arithmetic } \\
\text { Mean\% }\end{array}$ & $\begin{array}{l}\text { Standard } \\
\text { Deviation }\end{array}$ & $\begin{array}{c}\text { Importance } \\
\text { Level }\end{array}$ \\
\hline 36 & $\begin{array}{l}\text { The company is keen on developing an organizational culture that can be } \\
\text { felt at the level of performance }\end{array}$ & 4.200 & $84.0 \%$ & 0.569 & high \\
\hline 37 & $\begin{array}{l}\text { The behavior of workers in the company is consistent with, keeping up } \\
\text { the pace as well as supporting the change process. }\end{array}$ & 4.213 & $84.3 \%$ & 0.599 & High \\
\hline 38 & $\begin{array}{r}\text { The company has a clear and announced policy in the field of human } \\
\text { resources. }\end{array}$ & 4.253 & $85.1 \%$ & 0.572 & High \\
\hline 39 & $\begin{array}{l}\text { The company considers its employees as the most valuable resource } \\
\text { among its all available resources; it is keen to devote to this concept. }\end{array}$ & 4.133 & $82.7 \%$ & 0.644 & High \\
\hline
\end{tabular}


International Journal of Managing Information Technology (IJMIT) Vol.13, No.1, February 2021

\begin{tabular}{|c|c|c|c|c|c|}
\hline 40 & $\begin{array}{l}\text { The company constantly works to provide opportunities to rehabilitate its } \\
\text { employees to keep up with the continuous process of change in the work } \\
\text { environment. }\end{array}$ & 4.093 & $81.9 \%$ & 0.661 & High \\
\hline 41 & $\begin{array}{l}\text { The organizational structure and labor interrelations in the company } \\
\text { support achieving the highest performance by its employees. }\end{array}$ & 4.040 & $80.8 \%$ & 0.743 & High \\
\hline 42 & $\begin{array}{l}\text { The company is keen on providing the requirements and conditions of } \\
\text { readiness for its employees in order to face the process of transformation } \\
\text { and change. }\end{array}$ & 4.107 & $82.1 \%$ & 0.709 & High \\
\hline 43 & $\begin{array}{l}\text { The company has an appropriate recruitment, contracting system and } \\
\text { policies that result in employees' satisfaction. }\end{array}$ & 3.920 & $78.4 \%$ & 0.896 & High \\
\hline 44 & $\begin{array}{l}\text { The company's work system achieves a good level of gratitude for the } \\
\text { effort and Competence of its workers. }\end{array}$ & 4.040 & $80.8 \%$ & 0.907 & High \\
\hline 45 & $\begin{array}{l}\text { The work system guarantees good and appropriate returns and incentives } \\
\text { for workers. }\end{array}$ & 3.987 & $79.7 \%$ & 0.893 & High \\
\hline \multicolumn{2}{|c|}{ The General Average of the Employee Competence cy Variable } & 4.019 & $80.4 \%$ & 0.830 & High \\
\hline
\end{tabular}

\section{THE RESULTS OF REGRESSION ANALYSIS AND HYPOTHESIS TESTING:}

\section{ANALYZING THE IMPACT OF APPLYING INFORMATION TECHNOLOGY ON EACH BUSINESS TRANSFORMATION VARIABLE:}

\section{A) The impact of information technology on operations in Jordanian telecommunications companies.}

It can be seen that the value of the correlation coefficient $(\mathrm{R})$ between information technology and operations amounted to "+ $51.6 \%$ " ; this indicates the existence of a strong positive correlation between the two mentioned earlier; the Adjusted "R Square" is about "25.6\%"; this means that information technology explains about a quarter of the change in the dependent variable which is the operations in the Jordanian operating telecommunications companies. However, as for the statistic value (F), it reached "26.430"; furthermore, its level of significance reached " $0.00 \%$ " which is less than the level of significance that was used (5\%); accordingly, this indicates the suitability of the model used in the study.

Moreover, the beta constant which is represented by the alphabetical letter (B) relating to information technology was " 0.455 ", while and the value which is represented by the alphabetical letter (t) for this parameter was " 5.141 ", in addition, its level of significance was " $0.00 \%$ " which is less than the level of significance of the user, which was " $5 \%$ "; consequently, the first sub-hypothesis was rejected; it states that there is no statistically significant effect at the level of $(\alpha=0.05)$ for information technology relating to the operations in operating telecommunications companies in Jordan; however, the alternative hypothesis was accepted; it states that there is a statistically significant effect at a significant level. $(\alpha=0.05)$ for information technology on operations in telecom companies in Jordan.

\begin{tabular}{|l|c|c|c|}
\hline \multicolumn{1}{|c|}{ Variable } & Coefficient & T & Sig. \\
\hline \multicolumn{1}{|c|}{ Constant } & 0.466 & 5.998 & 0.000 \\
\hline \multicolumn{1}{|c|}{ IT } & 0.455 & 5.141 & 0.000 \\
\hline \multicolumn{2}{|c|}{ Model Summary } \\
\hline R & & 0.516 \\
\hline R Square & 0.266 \\
\hline Adj. R Square & & 0.256 \\
\hline Std. Error of the Estimate & & 0.08273 \\
\hline F & & 26.430 \\
\hline
\end{tabular}




\begin{tabular}{|l|r|}
\hline Sig. of F & 0.000 \\
\hline
\end{tabular}

\section{B) The impact of the information technology on the organizational change in the operating telecommunications companies in Jordan.}

Relating to the above-mentioned information relating to the correlation coefficient $(\mathrm{R})$ which was between the information technology variable and the organizational change variable which was "+ $60.3 \%$ "; this reflects a strong positive correlation between these two.

The Adjusted "R Square" was "35.4\%" which means that information technology explains more than onethird of the change in the dependent variable, which is the organizational change in Jordanian telecom companies.

However; the statistic value (F) was about " 41.615 ",; moreover, its level of significance was " $0.00 \%$ " which is less than the level of the meaningful user (5\%); accordingly, this indicates the suitability of the model as well as its validity in order to predict the level of the organizational change in the operating telecommunications companies in Jordan ; this is attained by knowing the level of the application of the information technology.

The beta coefficient (B) for information technology was " 0.483 ", while the value (T) for this parameter was "6.451"; the level of significance was " $0.00 \%$ " which is basically less than the level of the user morale of "5\%"; this result reflects that there is a positive impact of the information technology on the organizational change in the Jordanian operating telecommunications companies, Therefore, the second sub-hypothesis was rejected which states that there is no statistically significant effect at the level of $(\alpha=0.05)$ for information technology on organizational change in the operating telecommunications companies in Jordan; however, he alternative hypothesis was accepted which states that there is a statistically significant effect at a significant level $(\alpha=0.05)$ for the information technology on the organizational change in the operating telecommunications companies in Jordan.

\begin{tabular}{|l|c|c|c|}
\hline \multicolumn{1}{|c|}{ Variable } & Coefficient & T & Sig. \\
\hline \multicolumn{1}{|c|}{ Constant } & 0.439 & 6.675 & 0.000 \\
\hline \multicolumn{1}{|c|}{ IT } & 0.483 & 6.451 & 0.000 \\
\hline \multicolumn{2}{|c|}{ Model Summary } \\
\hline R & & 0.603 \\
\hline R Square & 0.363 \\
\hline Adj. R Square & & 0.354 \\
\hline Std. Error of the Estimate & & 0.06996 \\
\hline F & & 41.615 \\
\hline Sig. of F & & 0.000 \\
\hline
\end{tabular}

\section{C) The impact of information technology on the Competence of workers in Jordanian telecommunications companies.}

That the correlation coefficient (R) between the information technology variable and the workers' Competence variable was $25.4 \%$, which reflects the low correlation between the two variables. As for Adjusted R Square, it reached 5.2\%, which means that information technology explains about 5\% of the change in the Competence of workers in Jordanian telecommunications companies. 
The statistic value (F) was "5.040"; however, the level of significance was "2.80\%" which is less than the level of significance used in the study of $5 \%$, which indicates the validity of the model that was used in the study.

The beta coefficient (B) for information technology was " 0.283 "; the value of $(0)$ for this parameter was "2.245"; moreover, its significance level of was " $2.80 \%$ " which is less than the level of user morale of " $5 \%$ "; this result reflects that there is a positive effect of the information technology on the Competence of workers in the Jordanian operating telecommunications companies; consequently, the third sub-article was rejected which states that there is no statistically significant effect at a significant level $(\alpha=0.05)$ for information technology on the Competence of workers in the telecommunications operating companies in Jordan; on the other hand, the alternative hypothesis was accepted which states that there is a statistically significant effect at a significant level $(\alpha=0.05)$ for the information technology on the Competence of workers in the operating telecommunications companies in Jordan.

\begin{tabular}{|l|c|c|c|}
\hline \multicolumn{1}{|c|}{ Variable } & Coefficient & T & Sig. \\
\hline \multicolumn{1}{|c|}{ Constant } & 0.573 & 5.171 & 0.000 \\
\hline \multicolumn{1}{|c|}{ IT } & 0.283 & 5.245 & 0.028 \\
\hline \multicolumn{2}{|c|}{ Model Summary } \\
\hline R & & 0.254 \\
\hline R Square & & 0.065 \\
\hline Adj. R Square & & 0.052 \\
\hline Std. Error of the Estimate & & 0.11788 \\
\hline F & 5.040 \\
\hline Sig. of F & & 0.028 \\
\hline
\end{tabular}

\section{THE RSULTS AND CONCLUSION:}

\section{THE RSULTS:}

The study has arrived at a number of results; the most important of these results is that the telecommunications companies in Jordan operating in the field of information technology have: good infrastructure, software and communications networks, in addition to having a developmental environment, systems and applications for the appropriate executive support.

Moreover, the operating telecommunications companies adopt the concept of business transformation as a comprehensive and strategic process towards achieving the goals and vision of the telecommunications company; this leads to the constant improvement of the business performance as well as raising Competence and effectiveness.

\section{THE CONCLUSION:}

The study has a number of recommendations to be offered as a result of this study;, the most important of these recommendations is that there is a need to develop and improve the infrastructure which can be achieved by: providing support and technical support, improving the development environment, systems as well as the applications of the executive support; furthermore, there is a need to improve and develop processes as well as to develop the organizational change and employees' participation also, the study recommended that there is a need to change the organizational structure in order to support the transformation of business and develop the Competence of employees so as to complement this transformation. 


\section{Tables:}

\begin{tabular}{|c|c|c|c|}
\hline \multicolumn{4}{|c|}{ The Questionnaire } \\
\hline \multicolumn{4}{|l|}{ The First Part: } \\
\hline \multicolumn{4}{|l|}{ The Demographic Information } \\
\hline \multicolumn{4}{|l|}{ Age: } \\
\hline Less than 30 years & 30-less than 40 years & 40-less than 50 years & More than 50 years \\
\hline
\end{tabular}

\begin{tabular}{|l|l|l|l|l|}
\hline \multicolumn{5}{|c|}{ Education } \\
\hline Instructional & College Diploma & Bachelor & Higher Diploma & M.A. or PhD \\
\hline \multicolumn{2}{|c|}{} \\
\hline
\end{tabular}

\begin{tabular}{|c|c|c|c|c|}
\hline \multicolumn{5}{|c|}{ The Occupation Level } \\
\hline Manager & Head of Dept. & Head of Division & Supervisor & Eng. Works \\
\hline Tech. Works & \multicolumn{2}{|c|}{ Administrative Works } & Other than that (list it) \\
\hline
\end{tabular}

\begin{tabular}{|l|c|c|c|}
\hline \multicolumn{4}{|c|}{ Years of Experience: } \\
\hline Less than 5 years & 5-less than 10 years & 10-less than 15 year & More than 15 year \\
\hline
\end{tabular}

\begin{tabular}{|l|l|l|l|}
\hline \multicolumn{5}{|c|}{ Years of Experience in the current company } \\
\hline Less than 5 years & 5-less than 10 years & 10-less than 15 year & More than 15 year \\
\hline
\end{tabular}

\section{Part Two:}

\section{The Questionnaire articles:}

\section{Kindly choose the appropriate option by marking it with an " $\mathrm{X}$ ".}

\section{First: The extent of performing of information technology}

\begin{tabular}{|c|c|c|c|c|c|c|}
\hline No. & item & $\begin{array}{l}\text { Strongly } \\
\text { Agree }\end{array}$ & Agree & Neutral & Disagree & $\begin{array}{l}\text { Strongly } \\
\text { Disagree }\end{array}$ \\
\hline \multicolumn{7}{|c|}{ Infrastructure } \\
\hline \multicolumn{7}{|c|}{$\begin{array}{l}\text { It refers to the basic level of architecture through which computing devices and equipment, system operating software, and data storage } \\
\text { units that enable the user to use development and implementation tools and various applications are linked. }\end{array}$} \\
\hline 1 & $\begin{array}{l}\text { The company has an integrated IT infrastructure in terms of } \\
\text { hardware, networks, system software and the necessary storage } \\
\text { capacities. }\end{array}$ & & & & & \\
\hline 2 & $\begin{array}{l}\text { The company has support and technical support for basic IT } \\
\text { resources (hardware, networks, software and storage media). }\end{array}$ & & & & & \\
\hline 3 & $\begin{array}{l}\text { The company has a flexible infrastructure to install various } \\
\text { applications and software in terms of hardware, }\end{array}$ & & & & & \\
\hline
\end{tabular}




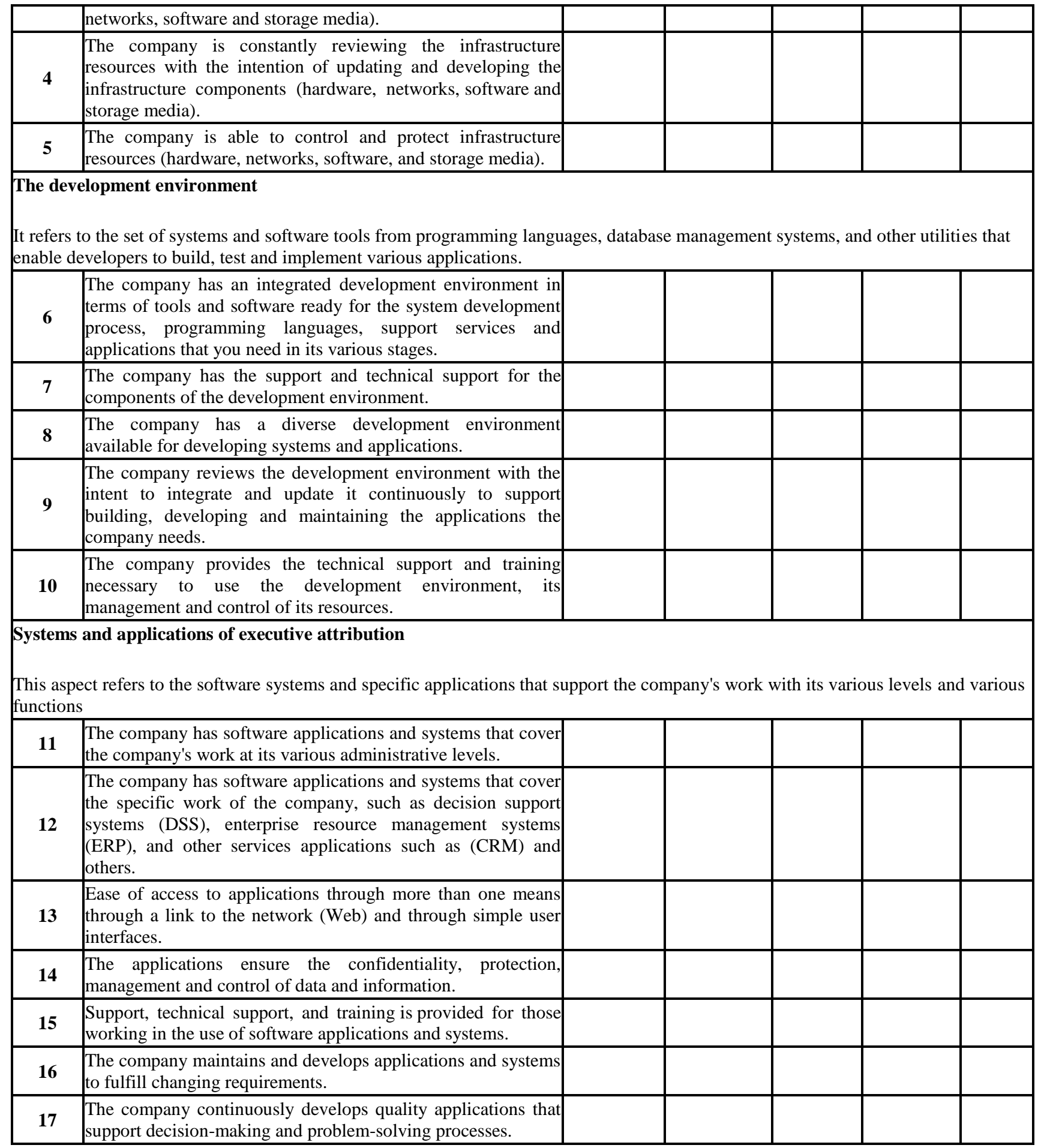

\section{Second: Measuring the business transformation}

\begin{tabular}{|c|c|c|c|c|c|c|}
\hline No. & item & $\begin{array}{l}\text { Strongly } \\
\text { Agree }\end{array}$ & Agree & Neutral & Disagree & $\begin{array}{l}\text { Strongly } \\
\text { Disagree }\end{array}$ \\
\hline \multicolumn{7}{|c|}{ Processes } \\
\hline
\end{tabular}




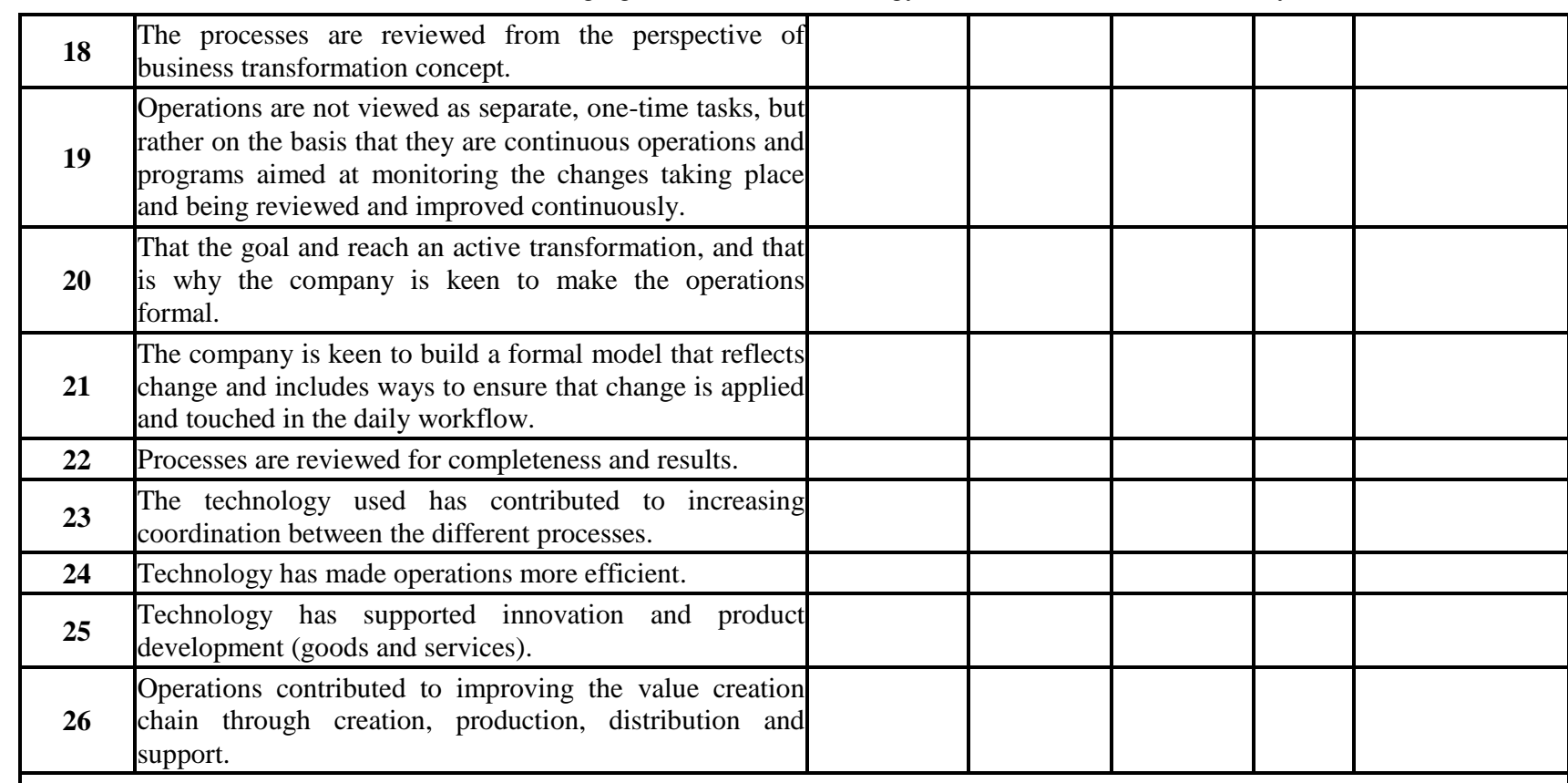

The Organizational change:

It refers to the structures, the systems and the processes that would enable the organization to control, compete, as well as provide it with efficiency, innovation, agility, success and sustainability.

\begin{tabular}{|c|c|c|c|c|c|c|}
\hline 27 & $\begin{array}{l}\text { Technology has contributed to a review of the company's } \\
\text { organizational structure, which is in line with the nature of } \\
\text { the business transformation. }\end{array}$ & & & & & \\
\hline 28 & $\begin{array}{l}\text { Technology has shaped the working relationships between } \\
\text { units and individuals in the company. }\end{array}$ & & & & & \\
\hline 29 & $\begin{array}{l}\text { Technology has contributed to the readiness of } \\
\text { performance and the way tasks and duties are distributed. }\end{array}$ & & & & & \\
\hline 30 & $\begin{array}{l}\text { The company reviews the organization's culture as it } \\
\text { aligns with the business transformation. }\end{array}$ & & & & & \\
\hline 31 & $\begin{array}{l}\text { Technology has contributed to reviewing and changing } \\
\text { the hierarchy of authority and permissions in the } \\
\text { organization. }\end{array}$ & & & & & \\
\hline 32 & $\begin{array}{l}\text { Technology has contributed to a reconsideration of the } \\
\text { lines of authority and permissions of superiors and } \\
\text { subordinates. }\end{array}$ & & & & & \\
\hline 33 & $\begin{array}{l}\text { The organizational structure has to have the ability to } \\
\text { change to transform in order to support a transforming } \\
\text { business model because of the influence of modern } \\
\text { technology as well as change in the business environment, } \\
\text { also the openness of environments due to globalization. }\end{array}$ & & & & & \\
\hline 34 & $\begin{array}{l}\text { Ensures performance under the business model on } \\
\text { improving the level and degree of cooperation, } \\
\text { coordination and participation among employees through } \\
\text { an organizational structure that ensures flexibility. }\end{array}$ & & & & & \\
\hline 35 & $\begin{array}{l}\text { The model supports the concept of sharing knowledge } \\
\text { among company's employees. }\end{array}$ & & & & & \\
\hline \multicolumn{7}{|c|}{$\begin{array}{l}\text { Workers' Efficiency } \\
\text { It refers to workers at all levels in terms of their readiness for the transformation process, which cannot happen without providing the } \\
\text { elements of readiness from the appropriate organizational competence that contribute to the transformation of workers' behavior, } \\
\text { through the organization's follow-up to work, contracting and appropriate employment policies. }\end{array}$} \\
\hline 36 & $\begin{array}{l}\text { The company is keen to develop an organizational culture } \\
\text { that can be felt at the level of performance. }\end{array}$ & & & & & \\
\hline 37 & $\begin{array}{l}\text { The behavior of workers in the company is consistent } \\
\text { with, keeps up, and supports the change process }\end{array}$ & & & & & \\
\hline
\end{tabular}




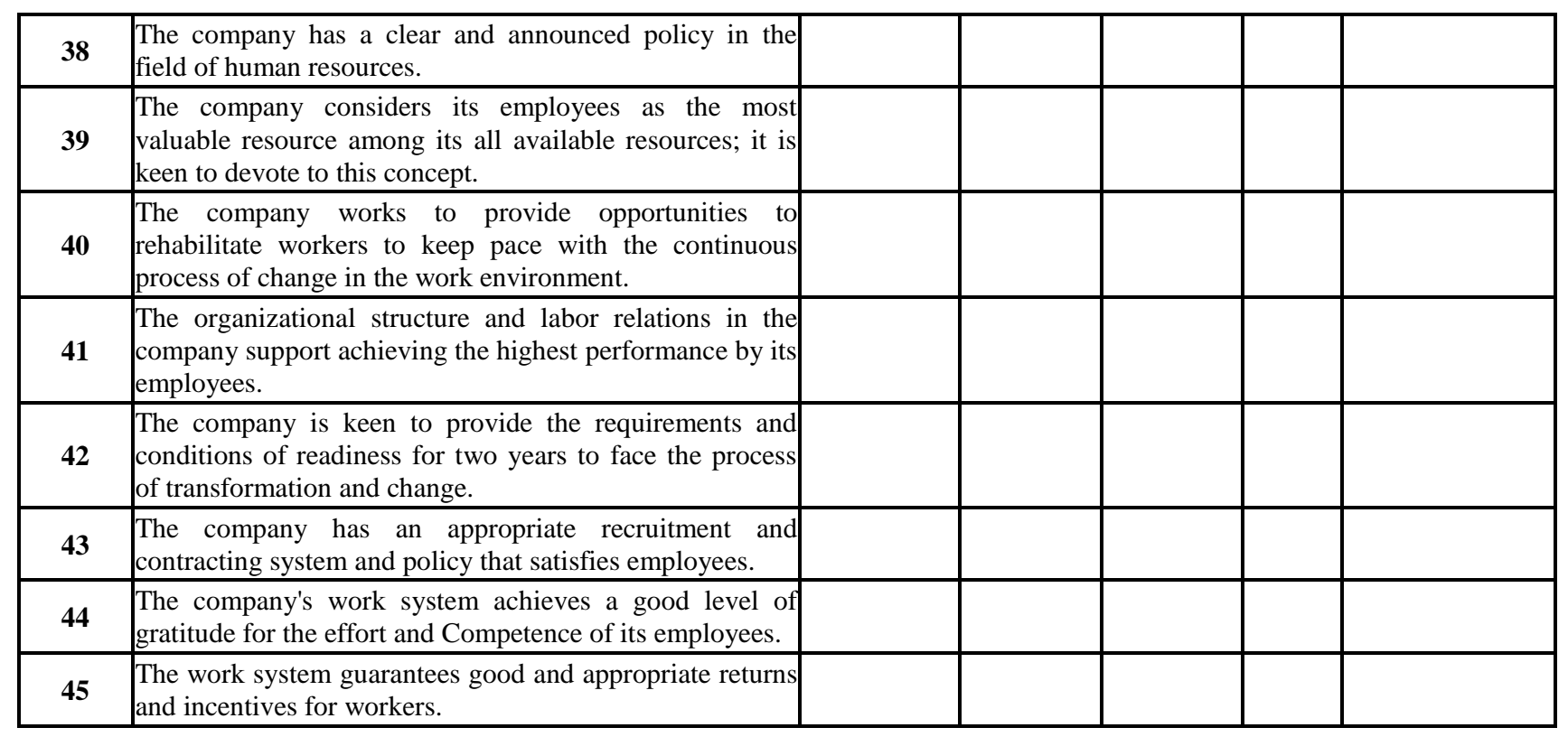

\section{References:}

A. E- Erdurmazl1- Jun 18, 2020, the Effects of Information Technologies on Organizational -Culture.

B. MA Marhraoui · 2017 International Journal of Computer Science \& Information Technology (IJCSIT), the emerging dynamic capabilities, Absorptive capacity and organizational agility.

C. SY -Zubaedah · 2017, the Successful Information Technology Adaptation Process for Organization agility, improved conceptualizing of the relationship between IT capabilities ...

D. AK Kariuki (2015) The Impact of information technology on organizational performance, the Relationship Between Information Technology Usage and Performance.

E. BA NOURI - 2020, the Effect of cooperative management on organizational agility

F. S-Panda - 2018- Information technology capability and knowledge management.

G. A- Ashrafi · 2019, the role of business analytics capabilities.

H. J-Cepeda $\cdot 2019$, The Information technology capabilities and organizational agility.

I. AT Walter - 2020, The Organizational agility: ill-defined and somewhat confusing

J. MF Lungu · 2020, The influence of strategic agility on firm performance.

K. Al Shobaki. 2018, The Reality of Computerized Management Information. 